\title{
Comparison of methods for determining the density of grass silage
}

\author{
Roy Latsch ${ }^{1}$ and Joachim Sauter ${ }^{1}$ \\ ${ }^{1}$ Agroscope Reckenholz-Tänikon Research Station ART, Tänikon 1, 8356 Ettenhausen, Switzerland \\ e-mail: roy.latsch@art.admin.ch
}

\begin{abstract}
In practice the only way to determine the bulk density of grass silage is to measure and weigh silage blocks. This study was carried out to compare this variant with four other measuring methods. "Big blocks" are inherently relatively heterogeneous and hence cannot be used for the fast, precise determination of density. "Small blocks" represent density well, but their handling makes them unsuitable for quick sampling. The three measuring methods - "drilling jig", "inclined drilling cylinder" and "vertical drilling cylinder" - gave comparable results. The "inclined drilling cylinder" was identified as the preferred variant on the basis of results and manageability.
\end{abstract}

Key words: grass-silage, bulk-density, measuring-methods, drilling-cylinders, block-cutter

\section{Introduction}

Good forage compaction is essential for the production of high quality grass silage. It minimises reheating and the energy loss accompanying the opening of a silo. Good compaction reduces oxygen diffusion in the forage pile, which should not exceed $20 \mathrm{I} \mathrm{m}^{-2} \mathrm{~h}^{-1}$ after opening the silo (Honig 1987). Under these conditions the area of silage favouring the activity of harmful aerobic organisms such as acetic acid bacteria and mould fungi is minimal, and the silage remains stable.

Thus far there have been no methods of determining bulk density during silo filling. Therefore, an assessment of compaction quality can only be made after a silo is opened. Silage blocks cut by a tractor-mounted block cutter are used to determine compaction as they are easy to extract, weigh and measure. Normally this type of sampling is not used at problem zones like the inclined end surfaces of a silage pile or, the silage edges along the wall sides because of their asymmetry. Drilling cylinders such as those used to determine the density of maize silage can be used for this purpose (Bundesarbeitskreis Futterkonservierung 2012). Due to the fibrous structures of grass silage, however, this method produces mechanical disturbance in the samples. Especially when the cutting process begins, the grass at the surface can be twisted due to its interwoven fibres and therefore loosened by rotating forces. At the first centimetres inside the cylinder, the shearing forces of the rotating cylinder work against the compound structure of the grass silage and can also loosen up and disturb the drilling core of the silage. An existing "Apparatus for obtaining an undisturbed core of silage" (Rees et al. 1983) has not become widespread to date. Moreover, there is no standard sampling procedure available. The relationship between bulk density and silage quality is therefore being studied in a research project at the Swiss Federal Research Station Agroscope Reckenholz-Tänikon (ART).

Within this framework different sampling methods were compared to identify the best possible sampling variant to evaluate the density of grass silage. The aim of this study was to compare different hand-held samplers with the "silage block" method and determine a preferred method. 


\section{Material and methods}

For this investigation, two horizontal silos were available. The stored green material originated from both natural grassland and temporary ley. The theoretical cutting length of the loader wagon involved was $40 \mathrm{~mm}$. Compaction was carried out by a standard ballasted tractor with a laden weight of $10230 \mathrm{~kg}$ and an internal tyre pressure of 2.5 bar. The mean overall bulk density of each silo investigated was recorded on the basis of the harvested product introduced and the measured overall volume of the forage pile. Unavoidable dry matter (DM) losses during the fermentation process that can amount up to 8-18\% (Bundesarbeitskreis Futterkonservierung 2012, Köhler et al. 2012) and the settlement of the silage pile were not regarded when calculating this mean silo bulk density.

One silage "big block" was taken from each horizontal silo for comparison. The mean DM content of the blocks was 26.6 and $30.7 \%$. The blocks were extracted with a Trioliet type TU 145 block cutter. Samples were subsequently taken from these two blocks with hand-held devices (Fig. 1).

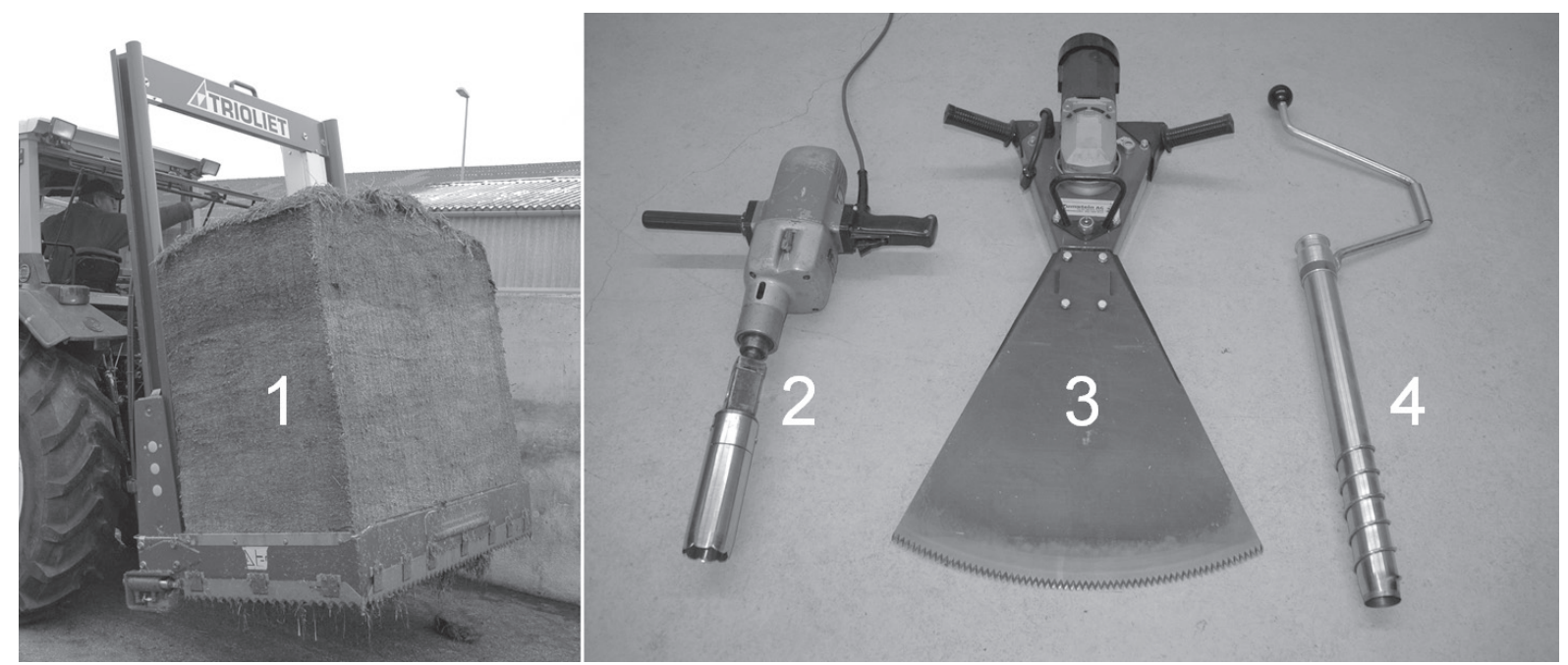

Fig. 1. Sampling devices used in the trial: 1: Silage block cutter (variant "big block"), 2: Drilling cylinder of ART (variants "drilling cylinder inclined" and "drilling cylinder vertical"), 3: Electric silage cutter (variant "small block"), 4: Pioneer ${ }^{\mathrm{TM}}$ drilling jig (variant "drilling jig")

A hand-held electric silage cutter (OMC AS/85) was used to cut out "small blocks". A preliminary test showed, that the work quality of both tested drilling cylinders differed depending on the drilling direction. Due to the small coarse teeth of the drilling jig (Pioneer ${ }^{\mathrm{TM}}$ ), that caused disturbances in the silage when drilling vertical and slid away when drilling inclined, the drilling jig was only used horizontally in this trail. The cone-shaped form of the jig prevented the silage from being pulled out of the cylinder at horizontal drilling direction. The volume of the samples taken with the drilling jig was determined by the drill hole diameter and the measured drill hole depth.

In contrast, the volume of the stainless steel drilling cylinder developed by ART was calculated, core drilling being limited to a defined length of $100 \mathrm{~mm}$ by slots in the drilling cylinder. This way to determine the volume of the sample should reduce the measurement error caused by loosened silage in the drilling cylinder port. Because the straight cylinder form could not prevent the silage from being pulled out of the horizontally used cylinder, this sampler was only used in vertical and inclined drilling direction. The ART drilling cylinder was driven electrically at $120 \mathrm{rpm}$. Coarse teeth were notched into the chamfered cutting edge in order to chop the grass silage thoroughly. Further technical data of samplers used are listed in Table 1.

Table 1: Technical data of samplers used

\begin{tabular}{|c|c|c|c|c|c|}
\hline variant & sampler & manufacturer & type & $\begin{array}{l}\text { sample dimensions } \\
(w \times d \times h)(m)\end{array}$ & $\begin{array}{l}\text { volume } \\
\left(\mathrm{m}^{3}\right)\end{array}$ \\
\hline "silo" & sensor bridge & ART (Ettenhausen, $\mathrm{CH}$ ) & ultrasonics & $6 \times 25.6 \times 1.4$ & 215 \\
\hline "big block" & block cutter & Trioliet (Oldenzaal, NL) & TU 145 & $1.75 \times 0.75 \times 1.2$ & 1.575 \\
\hline "small block" & electric silage cutter & OMC (Correggio, IT) & AS/85 & $0.2 \times 0.15 \times 0.2$ & 0.006 \\
\hline "drilling jig" & core drill & Pioneer (Buxtehude, DE) & Hi-Bred & $\varnothing 45 \mathrm{~mm} \times$ depth & variable \\
\hline "drilling cylinder" & core drill & ART (Ettenhausen, $\mathrm{CH}$ ) & & $\varnothing 56 \mathrm{~mm} \times 0.1$ & 0.00025 \\
\hline
\end{tabular}


As silage blocks can expand vertically when extracted from the pile, the layers for testing (each $0.2 \mathrm{~m}$ ) were premarked in the undisturbed silage. The height of the silage block was limited to $1.2 \mathrm{~m}$ for the trial. The precise measurements and weight of the silage blocks were determined following extraction.

Fig. 2 shows the 18 designated sampling locations at six different levels and in three repetitions. The volume and weight of all the samples were calculated to determine density. The trial was supplemented by pairwise comparisons of each of the sampling devices effected in the same manner directly in the silage pile.

Statistical analysis was carried out using a pairwise linear regression model (Tibco Spotfire S+, Somerville, MA, USA).

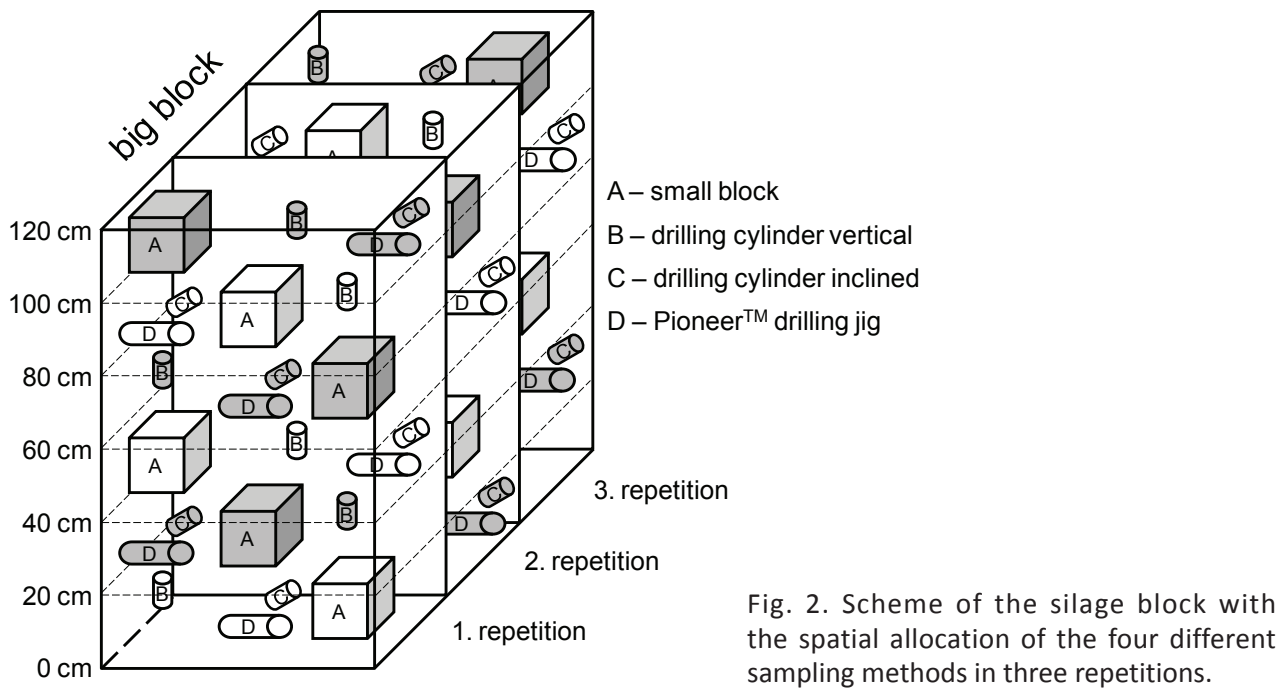

\section{Results and discussion}

The densities determined from the two silage blocks and the small blocks and core drillings taken from them, as well as the extra samples, are summarised in Table 2.

Table 2. Data to measured bulk density $\left(\mathrm{kg} \mathrm{FM} \mathrm{m}^{-3}\right)$

\begin{tabular}{|c|c|c|c|c|c|c|c|c|c|}
\hline \multirow[b]{3}{*}{ variant } & \multicolumn{6}{|c|}{ big block } & \multirow{2}{*}{\multicolumn{3}{|c|}{$\begin{array}{c}\text { extra samples } \\
\text { silo } 1\end{array}$}} \\
\hline & \multicolumn{3}{|c|}{ silo 1} & \multicolumn{3}{|c|}{ silo 2} & & & \\
\hline & $\begin{array}{r}\text { Mean } \\
(\mathrm{kg} \mathrm{Fn}\end{array}$ & $\begin{array}{r}S D \\
\left.m^{-3}\right)\end{array}$ & $\begin{array}{c}n \\
\text { (qty) }\end{array}$ & $\begin{array}{l}\text { Mean } \\
(\mathrm{kg} \mathrm{F}\end{array}$ & $\begin{array}{r}S D \\
\left.m^{-3}\right)\end{array}$ & $\begin{array}{c}\mathrm{n} \\
\text { (qty) }\end{array}$ & $\begin{array}{c}\text { Mear } \\
\text { (kg }\end{array}$ & $\begin{array}{r}S D \\
\left.m^{-3}\right) \\
\end{array}$ & $\begin{array}{c}\mathrm{n} \\
\text { (qty) }\end{array}$ \\
\hline "silo" & 690 & & 1 & 756 & & 1 & & & \\
\hline "big block" & 857 & & 1 & 880 & & 1 & & & \\
\hline "small block" & 800 & 123 & 15 & 824 & 82 & 15 & 791 & 143 & 11 \\
\hline "drilling jig" & 694 & 95 & 15 & 811 & 88 & 15 & & & \\
\hline "drilling cylinder inclined" & 769 & 117 & 15 & 768 & 101 & 15 & & & \\
\hline "drilling cylinder vertical" & 807 & 116 & 15 & 816 & 81 & 15 & 737 & 129 & 11 \\
\hline
\end{tabular}

SD: standard deviation, $\mathrm{n}$ : sample size

Compared with the target values put forward by Honig (1991) (800 kg FM m³ at 20\% DM content; $560 \mathrm{~kg} \mathrm{FM} \mathrm{m}^{-3}$ at 40\% DM content) the densities of both "big blocks" (27 and 31\% DM content), and hence of the overall silos, may be considered high. By comparison, the density of the "big block" from Silo 1 was $24 \%$ higher, the "big block" from Silo 2 16\% higher than that of the respective overall silo. The comparison of "big blocks" and "small blocks" demonstrates the enormous heterogeneity of silage blocks (Fig. 3). For example: the black squares in Fig. 3 repre-

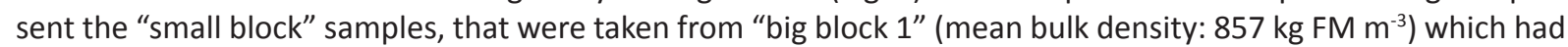
its source from silo 1 (mean bulk density: $690 \mathrm{~kg} \mathrm{FM} \mathrm{m}^{-3}$ ). The data show a huge heterogeneity not only in the different heights of the "big block", but also within the three repetitions of the same height. 


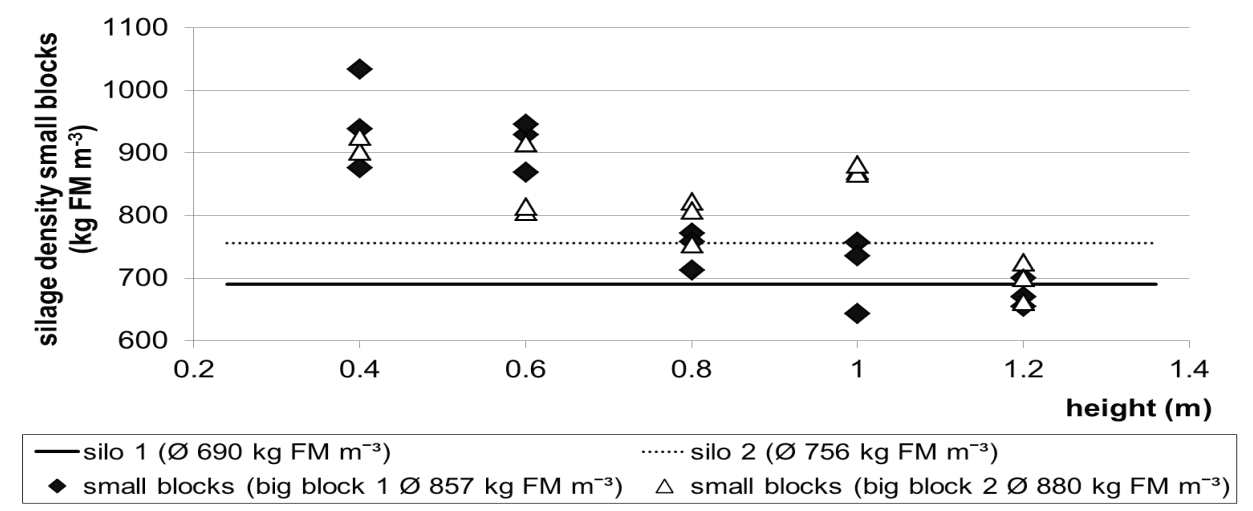

Fig. 3. Mean variation of silage density in big blocks determined by small block variant

An explanation for the not inconsiderable difference between "silo" and "big blocks" may be that the "big blocks" were taken from well compacted positions in the silage pile and not from problematic silo zones like the beginning and end, the wall areas or silage surfaces. Evaluation of the measurements confirms observations whereby density decreases as distance from the base plate increases (Craig and Roth 2005, D'Amours and Savoie 2005). Whole silage blocks are therefore only suitable for a quick assessment of the mean overall density of horizontal silos. The "small block" method was subsequently used as a reference for the comparability of selectively drawn samples.

Fig. 4 shows the values for the three drilling variants with reference to the "small block" variant. The residual standard error (Res. SE), as a measure of the dispersion of the data points around the regression line, is comparatively close together in the three drilling variants. Here the "inclined drilling cylinder" variant compares favourably with the other two variants due to lower dispersion, expressed by a lower Standard Error. But if, for example, the difference in the prediction accuracy of both drilling cylinder variants is calculated, these only differ by between 1 and $2 \%$. Both the gradient and the displacement of the regression lines to the $x=y$ line were calculated for $\mathrm{x}=869 \mathrm{~kg} \mathrm{FM} \mathrm{m}^{-3}$ (mean bulk density of both "big blocks"), but played a subordinate role in the given dispersion range of the values. All three variants underestimated the density of the reference "small block".

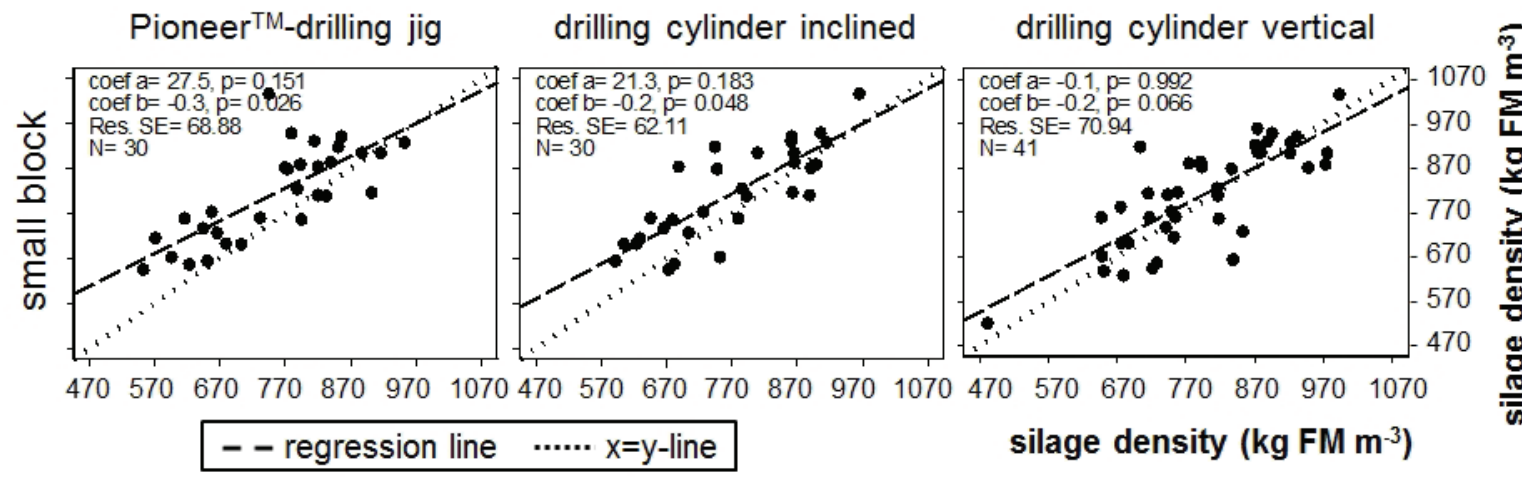

Fig. 4. Silage density of the drilling variants with reference to the small block (coef a: Shift of regression line from $x=y$-line in point $x=869 \mathrm{~kg} \mathrm{FM} \mathrm{m}^{-3}$, coef b: Difference in inclination between regression line and $\mathrm{x}=\mathrm{y}$-line, Res. SE: Residual Standard Error, $\mathrm{N}$ : number of samples) 
Kleinmans et al. (2005) and Thaysen et al. (2006) reported good results with the drilling jig in maize silage. Analogously to the results shown here, they also reported that the drilling jig tends to underestimate bulk density.

Horizontal drilling is recommended by Kleinmans et al. (2005) for the extraction of maize with the drilling jig. By comparison, the fibrous structure of grass silage results in the silage being pulled out of the drilling jig again during horizontal sampling and measurement of the drill hole depth reduces the calculated density. Drilling carried out at an angle to the horizontal bedding layers of the silage generally effects better separation of the grass silage fibres and the individual layers are no longer pulled out of the drilling jig.

The drilling cylinder used in this trial was driven by an electric drill. This represents a huge saving in labour, particularly when extracting a sizeable number of samples. An inclined drilling direction is preferable to a vertical one, as in this way samples can be taken at the cutting point of the silage.

\section{Conclusions}

Samples taken with hand-held devices testified to the enormous heterogeneity of density conditions within the silage blocks. A sizeable number of small silage samples represent the heterogeneous density conditions within horizontal silos whereas large-volume samples only express one single average. Drilling should be carried out obliquely or vertically in relation to the bedding direction of the fibres in order to cut the fibrous structure of the grass silage and to obtain good filling of the drilling cylinder. In statistical analysis the drilling variants tested showed only slight differences of between 1 and $2 \%$ in density prediction accuracy, the tendency being to underestimate the density compared to "small blocks". Rather better statistical consistency with the reference "small block" and comparatively easier handling made the "inclined drilling cylinder" variant the preferred variant in this trial.

\section{References}

Bundesarbeitskreis Futterkonservierung (ed.) 2012. Praxishandbuch Futter-und Substratkonservierung. 8. überarbeitete Auflage 2011. DLG-Verlag. 416 p. (in German).

Craig, P.H. \& Roth, G. 2005. Bunker silo density study - Summary report 2004-2005. Penn State University, Dauphin, PA, USA.

D’Amours, L. \& Savoie, P. 2005. Density profile of corn silage in bunker silos. Canadian Biosystems Engeneering 47. p. 2.21-2.28.

Honig, H. 1987. Gärbiologische Voraussetzungen zur Gewinnung qualitätsreicher Anwelksilage. Grünfutterernte und -konservierung KTBL-Schrift Nr. 318. p. 47-58. (in German).

Honig, H. 1991. Reducing losses during storage and unloading of silage. Landbauforschung Völkenrode Sonderheft 123: 116-128.

Kleinmans, J., Ruser, B., Oetjen, G. \& Thaysen, J. 2005. Eine neue Methode zur Bestimmung der Silageverdichtung - Einsatz des Probenbohrers in der Praxis. Mais 32: 134-136. (in German).

Köhler, B., Diepolder, M., Ostertag, J., Thurner, S. \& Spiekers, H. 2012. Dry matter losses of grass and maize silage in bunker silos. In: Kuoppala, K., Rinne, M. \& Vanhatalo, A. (eds.). XVI International Silage Conference. Hämeenlinna, Finland. p. 318-319.

Miller, A.M. 2006. Gute, stabile Maissilagen: Verteil- und Walzarbeiten entscheiden über den Erfolg. Milchpraxis 44: 118-119. (in German).

Rees, D.V.H., Audsley, E. \& Neale, M.A. 1983. Apparatus for obtaining an undisturbed core of silage and for measuring the porosity and gas diffusion in the sample. Journal of Agricultural Engineering Research 28: 107-114.

Thaysen, J., Ruser, B. \& Kleinmanns, J. 2006. Dichte Controlling - Bedeutung und Instrumente. In: Gesellschaft für Kunststoffe im Landbau e.V. GKL-Frühjahrstagung 2006 - Siliererfolg auch bei großen Erntemassen. Bonn. p. 14-17. (in German). 